Bulletin of the Zaporizhzhya State skladovi elementy orghanizacijnoEngineering Academy, no.2(1), pp. 111-116. ekonomichnogho mekhanizmu vykorystannja 9. Kljoba L. Gh. (2012). personalu promyslovykh pidpryjemstv [The Orghanizacijno-ekonomichnyj mekhanizm essence and constituent elements of the upravlinnja personalom [Organizational and organizational and economic mechanism for economic mechanism of personnel the use of personnel of industrial enterprises]. management]. Proceedings of the Problems and prospects of entrepreneurship Upravlinnja innovacijnym procesom $v$ Ukrajini: problemy komercializaciji naukovotekhnichnykh rozrobok : IV Mizhnarodna naukovo-praktychna videokonferencija (Ukraine, Lviv, May 23-24, 2012), Lviv, Vydavnyctvo Ljvivsjkoji politekhniky, pp. 137-138.

10. Curkan S. M. (2016). Sutnistj ta development, no. 2(1)., pp. C. $62-73$.

11. Yu. Lysenko, P. Egorov (1997). Organizatsionno-ekonomicheskiy mekhanizm upravleniya predpriyatiem [Organizationaleconomic mechanism of enterprise management]. Ekonomika Ukrainy . 1997. no.1, pp. $86-87$.

УДК 339.47:656.2

\title{
НАПРЯМКИ ЗАБЕЗПЕЧЕННЯ ЕКОНОМІЧНОЇ БЕЗПЕКИ ПІДПРИЕМСТВ ЗАЛІЗНИЧНОГО ТРАНСПОРТУ В ІНФОРМАЦІЙНІЙ СФЕРІ
}

\author{
Остапюк Б.Б., аспірант (УкрДУЗТ)
}

В статті встановлено, щзо інформаџія є одним з найцінніших ресурсів у світі, а iї захист є першочерговою проблемою для становлення та розвитку підприємств залізничного транспорту. Проведено детальний аналіз засобів захисту інформаційної безпеки підприємств залізничного транспорту, щуо дозволило виділити ключові з них та обтрунтувати напрямки економічної безпеки. Запропоновано удосконалити теоретичне підгрунтя стратегічного управління інформаційною безпекою підприємств залізничного транспорту за рахунок врахування багаторівневості системи управління, організаційно-ієрархічної структури залізничного транспорту та компонентів потенціалу забезпечення економічної безпеки залізничного транспорту.

Ключові слова: підприємство, залізничний транспорт, інформація, економічна безпека, стратегія, управління, ризики, засоби.

\section{НАПРАВЛЕНИЯ ОБЕСПЕЧЕНИЯ ЭКОНОМИЧЕСКОЙ БЕЗОПАСНОСТИ ПРЕДПРИЯТИЙ ЖЕЛЕЗНОДОРОЖНОГО ТРАНСПОРТА В ИНФОРМАЦИОННОЙ СФЕРЕ}

\section{Остапюк Б.Б., аспирант (УкрДУЖТ)}

В статье установлено, что информация является одним из самых иченных ресурсов в мире, а ее защита есть первоочередной проблемой для становления и развития предприятий железнодорожного транспорта. Проведен детальный анализ

(С) Остапюк Б.Б.

Вісник економіки транспорту і промисловості № 66, 2019 
средств защиты информаџионной безопасности предприятий железнодорожного транспорта, что позволило вылелить ключевые из них и обосновать направления экономической безопасности. Предложено усовершенствовать теоретические основь стратегического управления информационной безопасностью предприятий железнодорожного транспорта за счет учета многоуровневости системы управления, организачионно-иерархической структурь железнодорожного транспорта и компонентов потенщиала обеспечения экономической безопасности железнодорожного транспорта.

Ключевые слова: предприятие, железнодорожный транспорт, информация, экономическая безопасность, стратегия, управление, риски, средства.

\title{
DIRECTIONS FOR PROVIDING ECONOMIC SAFETY OF RAILWAY TRANSPORT COMPANIES IN THE INFORMATIONAL FIELD
}

\author{
Ostapyuk B. B., post-graduate student (USURT)
}

The article establishes that information becomes one of the most valuable resources in the world, and its protection is a priority problem for the establishment and development of rail transport enterprises. It is proved that at present there is a shift in attention from the effective organization of only information flows to improve the processes of making managerial decisions in accordance with the imperative of the development of the world economy and domestic railway transport. A detailed analysis of the means of information security protection of enterprises of railway transport was carried out, which allowed to identify the key ones and to substantiate the directions of economic security. It is inserted that for today one of the main organizational means of providing economic security in the information sphere should be the strategy of information security. It is proved that the strategy of information security of railway enterprises should be considered functional from the general strategy of economic safety of JSC "Ukrzaliznytsya" and an integral part of the general corporate strategy of railway transport. The theory of strategic management as a direction in science and practice is based on a large arsenal of scientific developments and concepts, but does not take into account the peculiarities of the development of railway transport. It is proposed to improve the theoretical basis for the strategic management of information security of railway enterprises by taking into account the multilevel governance system, organizational and hierarchical structure of railway transport and components of the potential of ensuring economic safety of railway transport, which will allow to purposefully and qualitatively approach the solution of the problem of ensuring the advanced development of railway transport in Ukraine.

Keywords: enterprise, railway transport, information, economic safety, strategy, management, risks, means.

Постановка проблеми. Існування сучасного світу неможливе без інформації та інформаційних технологій, вони стали невід'ємною частиною суспільства, а також кожного підприємства окремо. Інформаційні технології надають величезні можливості для спрощення і поліпшення всієї діяльності підприємств, особливо якщо це стосується такої організаційно та технологічно складної галузі як залізничний транспорт.

Проблеми вдосконалення базових положень управління економічною безпекою в інформаційній сфері в останні роки стають все актуальнішими для вітчизняних підприємств залізничного транспорту. Час випадкових кроків в управлінні проходить, настає час системної роботи, яка стає все більш складною, швидкою, a також максимально

Вісник економіки транспорту і промисловості № 66, 2019 
інформаційно й інтелектуально наповненою. У зв'язку з цим відбувається природне зміщення уваги 3 ефективної організації лише інформаційних потоків на удосконалення процесів прийняття управлінських рішень відповідно до імператив розвитку світової економіки та вітчизняного залізничного транспорту.

Аналіз досліджень та публікацій. Наразі теоретичне підгрунтя забезпечення інформаційної безпеки були висвітлені в працях: М. Понаріної, М. Лациби, Г. Резнікової, Л. Сороки [1 - 4] та ін.

Теоретико-методологічним основам управління розвитком залізничного транспорту України та забезпечення його економічної безпеки присвячені праці за авторством: В. Диканя, I. Токмакової, О. Маковоз, О. Шраменко, В. Овчиннікової, М. Корінь, А. Толстової, І. Харламової [57]та ін.

Віддаючи належне науковій i практичній значущості праць провідних учених, слід зазначити, що в сучасній науковій літературі й практиці господарювання АТ «Укрзалізниця» не враховані сучасні імперативи розвитку світової економіки та відповідно - нові особливості забезпечення економічної безпеки підприємств у інформаційній сфері.

Метою статті $\epsilon$ обгрунтування напрямків забезпечення економічної безпеки залізничного транспорту в інформаційній сфері.

Основний матеріал. Інформація сьогодні - важливий ресурс, втрата якого загрожує неприємними наслідками. Втрата конфіденційних

даних

AT «Укрзалізниця» несе в собі загрози не лише фінансових втрат залізничному транспорту, оскільки отриманою інформацією можуть скористатися конкуренти або зловмисники, але й економічним втратам бюджету держави та його транспортному потенціалу, адже мова йдеться про одну 3 найбільших компаній України. Для запобігання небажаних ситуацій підприємства залізничного транспорту вже наразі використовують різноманітні методи захисту інформації. Основним видом інформаційних загроз, для захисту від яких на підприємствах залізничного транспорту розробляється ціла низка технологій, $є$ несанкціонований доступ зловмисників до даних. Зловмисники планують заздалегідь злочинні дії, які можуть здійснювати шляхом прямого доступу до пристроїв або шляхом віддаленої атаки з використанням спеціально розроблених програм для отримання інформації.

Наразі крім дій хакерів, підприємства залізничного транспорту нерідко стикаються 3 ситуаціями втрати інформації через порушення роботи програмно-технічних засобів. В даному випадку секретні матеріали не потрапляють до рук зловмисників, проте втрачаються і не підлягають відновленню або відновлюються занадто довго. Збої в комп'ютерних системах можуть виникати 3 таких причин: втрата інформації внаслідок пошкодження носіїв - жорстких дисків, помилки в роботі програмних засобів, порушення в роботі апаратних засобів через пошкодження або знос.

Сучасні технології захисту даних грунтуються на застосуванні новітніх методів, які запобігають витоку інформації та іiі втраті. Сьогодні використовується сім основних методів (способів) захисту [2]: перешкода, маскування, механізми шифрування, регламентація, управління доступом, примус, спонукання. Всі перераховані методи націлені на побудову ефективної технології захисту інформації, завдяки якій виключаються втрати через недбалість персоналу і успішно запобігають різним видам загроз. Способи захисту інформації передбачають використання певного набору засобів. Для запобігання втрати i витоку секретних відомостей використовуються такі засоби [3]: фізичні, програмні i апаратні, організаційні, законодавчі, психологічні.

Фізичні засоби захисту інформації запобігають доступу сторонніх осіб на територію підприємств залізничного

Вісник економіки транспорту і промисловості № 66, 2019 
транспорту. Основними і найбільш поширеними засобами фізичної перешкоди $\epsilon$ міцні двері, надійні замки, решітки на вікнах. Для посилення захисту інформації використовуються пропускні пункти, на яких контроль доступу здійснюють люди (охоронці) або спеціальні системи. 3 метою запобігання втрат інформації також доцільна установка протипожежної системи. Фізичні засоби захисту використовуються для охорони даних як на паперових, так і на електронних носіях.

Програмні i апаратні (технічні) засоби - незамінний компонент забезпечення безпеки сучасних інформаційних систем. Апаратні засоби представлені пристроями, які вбудовуються в апаратуру для обробки інформації. Програмні засоби - програми, що запобігають хакерським атакам. Також до програмних засобів можна віднести програмні комплекси, що виконують відновлення втрачених відомостей. За допомогою комплексу апаратури та програм забезпечується резервне копіювання інформації для запобігання втрат. Аналіз стану справ у галузі технічного захисту інформації показує:

1. Сформувалася цілком повна концепція і структура, основу якої дозволив дійти висновків:

- актуальна і пророблена законодавча база, де досить чітко окреслена система поглядів на дану сферу діяльності;

- вельми розвинений арсенал технічних засобів захисту інформації, вироблених на промисловій основі;

- велика кількість підприємств, що спеціалізуються на вирішенні питань технічного захисту інформації;

- наявність значного практичного досвіду та ін.

2. Ефективність і відповідність заходів, що наразі вживаються в Україні, дозволяє забезпечити захист інформації від витоків технічними каналами відповідно до вимог діючих нормативно-методичних документів i технічних нормативних правових актів.
Незважаючи на всі вжиті в законодавстві заходів, злочинні дії 3 інформацією, не тільки не зменшуються, але й мають досить стійку тенденцію до зростання. Дослідження в цій галузі свідчать, що для боротьби із даною тенденцією не можна обмежуватися окремими і разовими заходами. Необхідний системний підхід, важливе і першорядне значення в якому відводиться безперервному розвитку та вдосконаленню науково-методологічних аспектів в галузі технічного захисту інформації.

По-перше, необхідне опрацювання i конкретизація пріоритетних наукових досліджень у галузі технічного захисту інформації саме для підприємств залізничного транспорту, що будуть враховувати особливості ї господарювання. Наукові дослідження в даній області не повинні бути сталими, вони потребують оновлення 3 урахуванням взаємодії i участі в цьому процесі: державних та комерційних організацій, а також спеціальних служб, які здатні надати інформацію фахівцям залізничного транспорту. Необхідне адекватне виявлення моделей загроз інформаційної безпеки. Потрібне подальше опрацювання питань кількісної оцінки ризиків та переваг, засноване на раціональних математичних моделях.

Пріоритетними

науковими дослідженнями щодо технічного захисту інформації підприємств залізничного транспорту, на наш погляд, повинні стати наступні напрямки:

1. Дослідження місця і ролі проблем технічного захисту інформації в становленні сучасного конкурентоспроможного залізничного транспорту.

2. Розробка і наукове обгрунтування системи моніторингу стану технічного захисту інформації підприємств залізничного транспорту.

3. Удосконалення нормативнометодичної бази проведення експертизи i контролю якості захисту інформації. 
4. Проблеми формування міжнародної системи в галузі технічного захисту інформації підприємств залізничного транспорту.

5. Дослідження, спрямовані на створення комплексу вітчизняних інструментальних засобів проектування засобів технічного захисту інформації.

6. Розробка і вдосконалення моделей загроз безпеки, систем i способів їх реалізації, визначення критеріїв уразливості i стійкості систем до деструктивних дій, розробка методів і засобів моніторингу для виявлення фактів застосування несанкціонованих інформаційних впливів, розробка методології та методичного апарату оцінки збитку від впливу загроз інформаційної безпеки підприємств залізничного транспорту.

7. Аналіз можливості використання досягнень фізики і техніки для отримання доступу до інформації, що обробляється на сучасних технічних засобах, в тому числі дослідження фізичних основ витоку інформації від технічних засобів по побічним каналам, розробка проблем аналітичної обробки побічних сигналів.

Законодавчі засоби захисту комплекс нормативно-правових актів, що регулюють діяльність людей, що мають доступ до охоронюваним відомостями i визначають міру відповідальності за втрату або крадіжку секретної інформації. В Україні у цьому напрямку активно ведеться робота, результатом якої $\epsilon$ закони та законодавчі документи [8-10].

Щодо психологічних засобів захисту інформації на підприємствах залізничного транспорту, то ними наразі $\epsilon$ комплекс заходів для створення особистої зацікавленості працівників у збереженні та автентичності інформації. Для створення особистої зацікавленості персоналу керівники підприємств галузі використовують різні види заохочень. До психологічних засобів відноситься i побудова корпоративної культури, при якій кожен працівник відчуває себе важливою частиною системи і зацікавлений в успіху підприємства.

Відносно організаційних засобів, то вони пов'язані 3 декількома методами захисту: регламентацією, управлінням, примусом. До організаційних засобів відноситься розробка посадових інструкцій, бесіди 3 працівниками, комплекс заходів покарання і заохочення. При ефективному використанні організаційних засобів працівники підприємств залізничного транспорту добре проінформовані про технології роботи 3 охоронюваними відомостями, чітко виконують свої обов'язки i несуть відповідальність за надання недостовірної інформації, витік або втрату даних.

На сьогоднішній день одним із головних організаційних засобів забезпечення економічної безпеки в інформаційній сфері повинна стати стратегія інформаційної безпеки. Враховуючи той факт, що управління процесами в інформаційній сфері не можна розглядати у відриві від загальних питань економічної безпеки, стратегію інформаційної безпеки підприємств залізничного транспорту слід вважати функціональною від загальної стратегії економічної безпеки АТ «Укрзалізниця» та складовою загальнокорпоративної стратегії залізничного транспорту.

Незважаючи на прийняті в залізничній галузі заходи, спрямовані на реалізацію політики стратегічного управління в сфері забезпечення інформаційної безпеки підприємств залізничного транспорту - до теперішнього часу вона не набула остаточних характеристик. Звісно ж, що в певній мірі це пов'язано зі складністю розуміння тонкощів і нюансів даного процесу та недостатньою розробленістю алгоритму застосування його в практичній діяльності. На сьогоднішній день теорія стратегічного управління як напрям в науці i практиці базується на значному арсеналі наукових розробок i концепцій: теорії наукової організації праці та соціології управління, теорії соціальних

Вісник економіки транспорту і промисловості № 66, 2019 
явищ, загальної теорії систем, кібернетиці, концепції стратегічного моделювання i планування, сучасної філософії менеджменту, теорії управлінських рішень, теорії формування стратегії як колективного процесу, науковому управлінні суспільством і т. ін.

$$
\text { Сучасні науковці головною }
$$

складовою стратегічного управління вважають стратегію, поліпшення технології прийняття рішень та їх виконання. Проблемою стратегічного управління $\epsilon$ його розвиток в якості самостійного практичного спрямування в сфері інформації, а також побудова теоретичної концепції в рамках теорії управління. В даний час існує лише приблизна загальноприйнята концептуальна модель, враховуючи яку необхідно побудувати теоретичне підгрунтя для стратегічного управління інформаційною безпекою підприємств залізничного транспорту, яке на нашу думку повинно враховувати багаторівневість системи управління, організаційно-ієрархічну структуру залізничного транспорту та компоненти потенціалу забезпечення економічної безпеки залізничного транспорту.

Виходячи 3 викладеного, наразі в умовах світової глобалізації та діджиталізації економіки вельми необхідним є, в першу чергу, стратегічне управління інформаційною безпекою підприємств залізничного транспорту, яке, в свою чергу, доцільно розглядати в якості унікальної системи, яка повинна своєчасно розпізнавати проблеми, висувати науковообгрунтовані стратегічні цілі, шляхи та способи їх досягнення; формувати уявлення про стан системи в майбутньому зі збереженням традиційних і придбанням (створенням) нових здібностей i можливостей управління, підлаштовуються під мінливі і можливості, що відкриваються; своєчасно встановлювати i розпізнавати можливості i загрози, що виходять із зовнішнього середовища; виробляти способи зміни зовнішнього оточення, реформування залізничної галузі, системи стратегічного та оперативного управління в міру збільшення власного потенціалу, виконання загально корпоративних стратегічних завдань.

Висновки. В умовах зростання інформаційних потоків та ускладнення взаємовідносин в бізнес-середовищі, що обумовлені становленням цифрової економіки, інформація стає одним 3 найцінніших ресурсів у світі, а іiі захист першочерговою проблемою для становлення та розвитку підприємств залізничного транспорту. Детальний аналіз засобів захисту інформаційної безпеки підприємств залізничного транспорту дозволив виділити ключові 3 них та визначити напрямки їх удосконалення, що дозволить цілеспрямовано та якісно підійти до вирішення проблеми забезпечення випереджаючого розвитку залізничного транспорту України.

\section{ПЕРЕЛІК ВИКОРИСТАНИХ ДЖЕРЕЛ}

1. Понарина Н.Н. Глобализация и информационное общество / H.Н. Понарина // Общество: політика, экономика, право. - 2012. - №1. - С. 19 - 24.

2. Методичні рекомендації щодо практичного впровадження Закону України «Про доступ до публічної інформації» / М.В. Лациба // Укр. незалежн. центр політ. дослідж. - К.: Агенство «Україна», 2011. $144 \mathrm{c}$.

3. Резнікова Г.I. Професійна таємниця: поняття, ознаки та види / Г.I. Резнікова //Трибуна докторанта, аспіранта і здобувача . 2013. - Вип. 26. - С. 280-292.

4. Сорока Л. С. Захист облікової інформації в системі економічної безпеки підприємства / Л. С. Сорока // Економічні науки. - Серія «Облік і фінанси», 2012. Вип. 9 (3). - С. 315-321.

5. Дикань В.Л. Основи бізнесу : навчальний посібник / В.Л. Дикань, В.О. Овчиннікова, І.В. Токмакова, М. В. Корінь, А. В. Толстова. - Х.: УкрДУзТ, 2018. - 290 c.

Вісник економіки транспорту і промисловості № 66, 2019 
6. Дикань В.Л. Стратегічне управління: навчальний посібник / В.Л. Дикань, В.О. Зубенко, О.В. Маковоз, I.В. Токмакова, О.В. Шраменко. - К.: «Центр учбової літератури», 2013. - 272 с.

7. Овчиннікова В. О. Адаптивне управління залізничним транспортом України / В. О. Овчиннікова, I. М. Харламова // Науковий вісник Ужгородського національного університету, 2017. - Вип. 15(2). - С. 55-59.

8. Стратегія розвитку інформаційного суспільства в Україні : Розпорядження Кабінету Міністрів України від 15.05.2013 р. №386-p.

9. Про основні засади розвитку інформаційного суспільства в Україні на 2007 - 2015 роки : Закон України від 09.01. 2007 р. // Відомості Верховної Ради. - 2007. - № 12. - Ст. 102.

10. Про захист економічної конкуренції : Закон України від 11.01.2001 р. // Відомості Верховної Ради. - 2001. - № 12. - Ст. 64.

11. Про допуск до публічної інформації : Закон України від 13.01.2011 р. // Офіційний Вісник України. - 2011. - № 10. - C. 29. - C.446.

\section{REFERENCES}

1. Ponomaryna N.N. Hlobalyzatsyya y ynformatsyonnoe obshchestvo (2012) [Globalization and the Information Society], Society: Politics, Economics, Law, No. 1, P. 19 - 24.

2. Metodychni rekomendatsiyi shchodo praktychnoho vprovadzhennya Zakonu Ukrayiny «Pro dostup do publichnoyi informatsiyi» [Methodical recommendations on the practical implementation of the Law of Ukraine "On access to public information"] (2011), M.V. Laciba, Ukr. independent center flight. Research, K .: Agency "Ukraine", 144 p.
3. Reznikova G.I. (2013) Profesiyna tayemnytsya: ponyattya, oznaky ta vydy [Professional secret: concepts, features and types] Tribunal of the doctorate, postgraduate and applicant, Issue 26, P. 280-292.

4. Soroka L. S. (2012) Zakhyst oblikovoyi informatsiyi v systemi ekonomichnoyi bezpeky pidpryyemstva [Protection of Accounting Information in the System of Economic Security of the Enterprise], Economics, Series Accounting and Finance, Issue. 9 (3), P. 315-321.

5. Dukan V.L., Tokmakova I.V., Ovchynnikova V.O., Korin M.V., Tolstova A.V. (2017) Osnovy biznesu [Establish business: tutorial]. Khakiv: UURT, 291 p. (in Ukrainian)

6. Dukan V.L., Tokmakova I.V., Zubenko V.O., Makovoz O.V., Shramenko O.V. (2013) Strategichne upravlinnya [Strategic management] K.: «Centr uchbovoy literatury», 272 p. (in Ukrainian)

7. Ovchynnikova V.O., Kharlamova I. M. (2017) Adaptyvne upravlinnya zaliznychnym transportom Ukrayiny [Adaptive management of railway transport of Ukraine] Scientific herald of Uzhhorod National University, No 15 (2). - pp. 55-59.

8. Strategy of the development of the information society in Ukraine (2013) Order of the Cabinet of Ministers of Ukraine dated May 152013 , No. 386-p.

9. On the Basic Principles of the Information Society Development in Ukraine for 2007-2015: Law of Ukraine dated 09.01.2007, Bulletin of the Verkhovna Rada, No. 12, Art. 102.

10. On the Protection of Economic Competition: The Law of Ukraine of January 11, 2001, Vestomosti of the Verkhovna Rada, No. 12, Art. 64.

11. About admission to public information: Law of Ukraine dated January 13, 2011, Official Bulletin of Ukraine, No. 10, P.446. 